\title{
The Influence of Personal Characteristics on Performance through Entrepreneurial Behavior of Muntok Pepper Farmers
}

\section{Rufti Puji Astuti * (D), Novyandra Ilham Bahtera (D), Eddy Jajang Jaya Atmaja (D, and Igu Sandira}

Department of Agribusiness, Faculty of Agriculture, Fisheries, and Biology, Universitas Bangka Belitung, 33172, Bangka, Bangka Belitung Islands Province, Indonesia

* Corresponding Author: ruftipuji24@gmail.com

\section{ARTICLE INFO}

Publication Info:

Research Article

How to cite:

Astuti, R. P., Bahtera, N. I., Atmaja, E. J. J., E Sandira, I. (2020). The Influence of Personal Characteristics on Performance through Entrepreneurial Behavior of Muntok Pepper Farmers.

Society, 8(2), 818-835.

DOI: $10.33019 /$ society.v8i2.249

Copyright (C) 2020. Owned by Author(s), published by Society

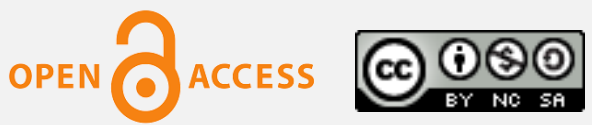

This is an open-access article.

License: Attribution-

NonCommercial-ShareAlike (CC BY-NC-SA)

\begin{abstract}
Currently, the performance of the pepper Muntok business continues to decline from time to time. This condition needs to be supported by studying the characteristics of farmers as human resources who carry out business planning and decision-making faced with various threats, challenges, and uncertainties. This study aims to 1) determine personal characteristics; 2) analyze the effect of personal characteristics on entrepreneurial behavior, 3) analyze the effect of personal characteristics and entrepreneurial behavior of farmers on business performance; and 4) analyze the effect of entrepreneurial behavior on business performance. The research method uses a survey method involving 90 farmers. Data analysis was carried out using Structural Equation Modeling (SEM) through Smart Partial Least squares (PLS). The results showed that the personal characteristics of the dominant farmer were strongly reflected by indicators of ethnic origin, experience, and age. Personal characteristics positively and significantly contribute to entrepreneurial behavior, and positive entrepreneurial behavior significantly influences business performance. The study results did not directly influence personal characteristics on business performance but through entrepreneurial behavior. Furthermore, the indicator variables of ethnic origin, experience, and age affect discipline, persistence, perseverance, interest in seeking and increasing knowledge, and mastery of technical skills, which can ultimately determine the level of business productivity and the desire to grow through business expansion. Before and during the COVID-19 pandemic, the entrepreneurial behavior of farmers was still strongly shaped by cognitive and affective variables. It is necessary to increase the skills of farmers
\end{abstract}

Copyright (C 2020. Owned by Author(s), published by Society. This is an open-access article under the CC-BY-NC-SA license. 

Muntok Pepper Farmers

Received: October 18, 2020;

Accepted: December 22, 2020;

Published: December 31, 2020; through training and entrepreneurship development that pays attention to personal characteristics to improve business performance. This study can recommend the Agriculture Office of the Bangka Belitung Islands Province in formulating policies to increase the productivity of pepper plants and the welfare of pepper farmers in the future.

\section{Keywords: Entrepreneurship; Performance; Personal Characteristics; Pepper Farmer}

\section{Introduction}

Data from FAOSTAT (2019) shows that pepper production in Indonesia only contributes less than one-quarter of pepper production for the world's needs or, to be precise, at $13 \%$. This is not surprising because data from the same source shows that there has been a decline in pepper exports in Indonesia starting in 2014. Figure 1 shows an increase in the value of exports from 19,100 tons in 1961 to 236,062 tons in 2017, which recorded a 12 times increase for more than five decades. However, the export value fell drastically by $43 \%$, decreasing from 548,193 tons in 2015 to 236,062 in 2017. This is an important indication that it is possible to change the personal characteristics of pepper farmers so that their performance is reduced.

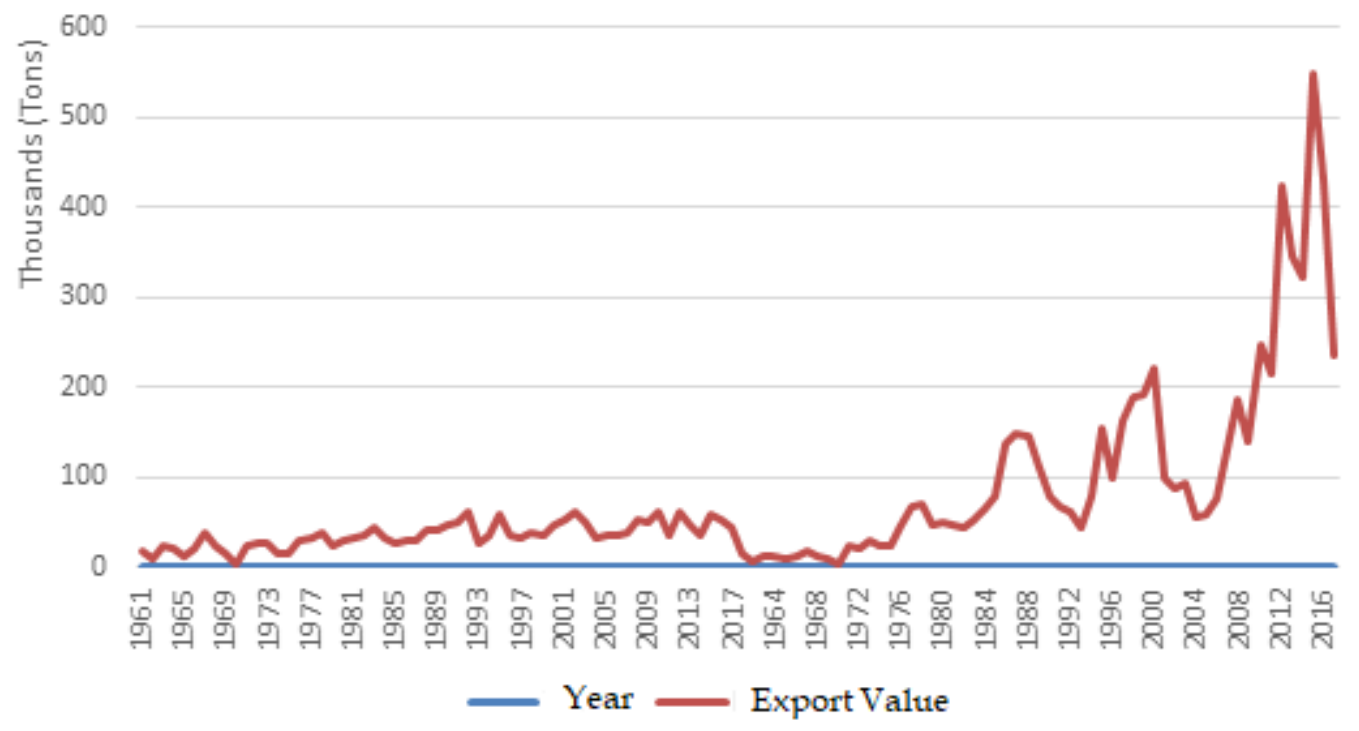

Figure 1. Indonesian Pepper Exports based on 1961-2017 Source: FAOSTAT (2019)

It is known that the characteristics of pepper farmers on Bangka Island are entrepreneurial: discipline and perseverance in pepper commodity farming activities (Astuti et al., 2019). This can be explained by entrepreneurial characteristics such as being willing to take risks, being responsive in taking advantage of opportunities, fighting spirit, and being innovative. However, there is ambiguity where the data has shown that pepper farmers' farming business performance has decreased in export value. At the same time, the value possessed by pepper farmers can make them productive in producing pepper plants. 


\section{The Influence of Personal Characteristics on Performance through Entrepreneurial Behavior of Muntok Pepper Farmers}

Islam et al. (2011) stated that entrepreneurial characteristics significantly determine business success in the MSME sector. This factor is the long year that an organization has been established which is the determining factor in doing business in the MSME sector. In essence, business actors who have been in the business world for a long time tend to be more successful than relatively new ones. In addition, gender also influences the success of MSME scale businesses. This shows that the personal characteristics of MSME scale business actors influence business performance.

Meanwhile, psychological characteristics such as hard work, discipline, risk-taking, vision, innovation, confidence, and responsible have a significant positive influence on success in the MSME world (Jumaedi, 2012; Miftakhuljanah et al., 2016). However, few know that enthusiasm for the natural environment (de Bernardi \& Pedrini, 2020). This means that the environmental conditions of an entrepreneur's community can change the entrepreneurial behavior of an entrepreneur. The same thing was also found by Calza et al. (2020), who said that cultural values could influence entrepreneurial activities. This shows that culture can be determined by shaping a person's entrepreneurial behavior in a country.

A study by Bannor et al. (2020) shows that farmers tend to have low to medium levels of entrepreneurial behavior. Bannor et al. (2020) suggested that market information and valueadded knowledge positively influence the level of entrepreneurial behavior in Ghana. This entrepreneurial behavior can be formed by the subconscious of every individual, which starts from dreams, business ideas, and the creation of a new business (Metallo et al., 2020). The values held by a group of people are important in determining a person's entrepreneurial behavior (Calza et al., 2020). In addition, business networks and institutional support are also important for how someone has entrepreneurial attitudes, orientations, and actions (Donbesuur et al., 2020).

The studies described focus more on how the MSME sector's personal characteristics and entrepreneurial behavior influence business performance. However, there are still not many studies on farmers as business actors in the agricultural sector. On this basis, this study aims to identify the personal characteristics of pepper farmers, examine the impact of personal characteristics on entrepreneurial behavior, and determine the effect of personal characteristics and entrepreneurial behavior on farm business performance.

\section{Literature Review}

Personal characteristics provide an overview of the personal characteristics of an individual. Personal characteristics were used in several previous studies, and the indicator variables used were age, experience, education, training, and family roles (Li, 2009; Puspitasari et al., 2013; Sumantri et al., 2013; Brush et al., 2010). Age, gender, and experience are also associated as personal characteristics from the demographic aspect. The results of previous studies stated that the age of 25 to 45 years is the age that shows someone is most active in entrepreneurship (Miftakhuljanah et al., 2016). Likewise, people who have previous experience in entrepreneurship will have a greater interest in developing a business than people who have never had entrepreneurial experience (Dirlanudin et al., 2010; Islam et al., 2011; Kellermanns et al., 2008; Riyanti, 2003; Sapar et al., 2006) and are more likely to share experiences with less experience (Yulia \& Bahtera, 2020). The influence of personal characteristics on entrepreneurial abilities is expected to affect business performance. This assumption is supported by Nurhayati (2011) which states that the psychological characteristics of entrepreneurship have a real and positive effect on entrepreneurial competence and business performance.

Copyright (C) 2020. Owned by Author(s), published by Society. This is an open-access article under the CC-BY-NC-SA license. https://doi.org/10.33019/society.v8i2.249

820 
Entrepreneurial behavior is formed from the behavior of an entrepreneur, which consists of knowledge (cognitive), mental attitude (affective), and skills (motoric). Attitude is one of the indicator variables that shape behavior in every action. Nurfitriya (2013) states that entrepreneurial attitude tends to think, feel, and behave as an entrepreneur in work that leads to finding, creating, applying new ways of working, technology and products, increasing efficiency, and obtaining greater profits.

Individual internal factors influence entrepreneurial behavior through efforts to motivate, innovation, and the courage to take risks (Priyono \& Burhanuddin, 2020). The results of previous studies found the influence of entrepreneurial behavior on business performance. A positive and significant contribution was found in the causal relationship of the entrepreneurial behavior of rubber farmers in Jambi, orchid farmers, and tempeh producers in Bogor on business performance. Variables of entrepreneurial behavior include attitudes (affective), knowledge (cognitive), and skills (motoric), diligent effort, responsiveness to opportunities, innovation, risk-taking, and independence (Nursiah et al., 2017; Puspitasari et al., 2013).

Business performance is a measure of a business run by a flourishing or successful entrepreneur. According to Sari et al. (2016), business performance is influenced by individual and psychological characteristics. Jumaedi (2012) identified business success in four indicators: achieving business goals, products accepted by the market, production profits, and entrepreneurial inner satisfaction. Meanwhile, Islam et al. (2011) stated that business success could be measured by the level of survival, profit, investment returns, company sales, number of workers, happiness, and reputation. Business performance can also be measured from income and business productivity indicators (Irawati \& Yantu, 2015). Business performance can be improved by conducting training that can increase productivity and profits (Kuntariningsih \& Mariyono, 2013) and through empowering farmers (Bahtera et al., 2016).

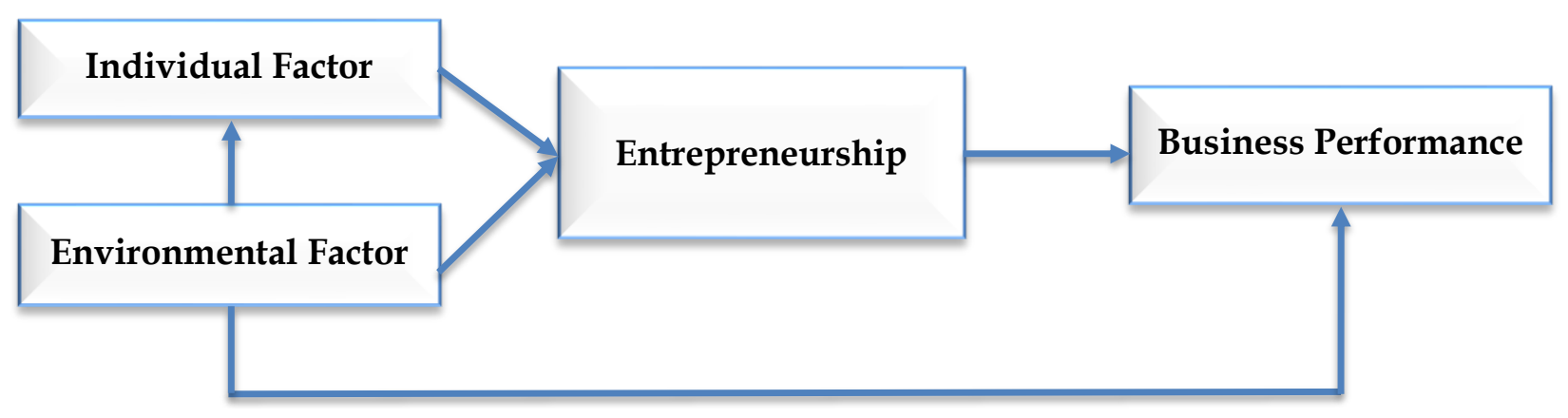

Figure 2. General models of entrepreneurial behavior and business performance Source: adapted from Delmar (1996)

This study was conducted to examine the effect of personal characteristics on business performance and entrepreneurial behavior of Muntok pepper farmers. Individual internal factors, namely personal characteristics, influence farmer entrepreneurship, as described in the general model of entrepreneurial behavior and business performance adopted from Delmar (1996) in Figure 2. Business performance variables in the model built are influenced by internal factors, namely through the entrepreneurial variable. This study was conducted to see how the internal factors of personal characteristics influence business performance directly or indirectly through entrepreneurial behavior variables. 


\section{Research Methodology}

\subsection{Location and Time of Research}

The research was conducted in South Bangka Regency, Bangka Regency, and Central Bangka Regency. The research was conducted for six months, starting from April 2020 to September 2020. The reason for choosing the location was because, in South Bangka Regency, Bangka Regency, and Central Bangka Regency, respondent farmers had previously identified entrepreneurial characteristics and entrepreneurial behavior in managing farming from previous research.

\subsection{Data Types and Sources}

The types of data used in this study are primary and secondary data. Primary data were obtained from information sources through observation, interviews, and discussions, guided by the questionnaire. Secondary data were obtained from related institutions and literature studies. Primary data taken include data on personal characteristics of farmers, data on entrepreneurial behavior, and business performance. The secondary data taken in this study are pepper production and export data.

\subsection{Sampling Method}

The research method used is the survey method, involving 90 farmers as respondents. The researcher used a simple random sampling method in determining the research sample. The number of samples taken proportionally from each sub-district is 30 farmers.

\subsection{Design, Processing Methods, and Data Analysis}

The data that has been obtained is then processed and analyzed descriptively, both qualitatively and quantitatively. Quantitative data were processed with the help of the Microsoft Excel 2010 application and analyzed by Structural Equation Modeling (SEM) analysis using smart partial least squares (PLS). The data analysis process is carried out through 2 stages: the Outter Model (measurement model) and the Inner Model (structural model). Evaluation of the measurement model is done by looking at the Loading Factor $(\lambda)$ value. It is valid if it has a Loading Factor $(\lambda)$ value greater than 0.5 . The significance test in evaluating the structural model is based on the estimated path parameter coefficient value, and the $t$-value is more than 1.96. The significance test of the estimated path parameter coefficients was carried out using the resampling method, namely bootstrapping (Ghozali \& Latan, 2012). The research variables observed in detail can be seen in (Table 1).

Table 1. Observed research variables

\begin{tabular}{lll}
\hline No & \multicolumn{1}{c}{ Latent Variable } & Manifest Variable \\
\hline 1 & Personal Characteristics PC & Education $(\mathrm{X} 1.1)$ \\
& $(\mathrm{X} 1)$ & Age $(\mathrm{X} 1.2)$ \\
& & Business experience $(\mathrm{X} 1.3)$ \\
& & Ethnic $(\mathrm{X} 1.4)$ \\
2 & Entrepreneurial Behavior EB & Affective $(\mathrm{Y} 1.1)$ \\
& $(\mathrm{Y} 1)$ & Cognitive $(\mathrm{Y} 1.2)$ \\
& & Motoric $(\mathrm{Y} 1.3)$
\end{tabular}

Copyright (C) 2020. Owned by Author(s), published by Society. This is an open-access article under the CC-BY-NC-SA license. 


\begin{tabular}{lll}
\hline No & \multicolumn{1}{c}{ Latent Variable } & \multicolumn{1}{c}{ Manifest Variable } \\
\hline 3 & Business Performance BP & Ability to maintain existence (Y2.1) \\
& Comparison of the number of current and initial \\
& plantings (Y2.2) & Comparison of increase in planting area (Y2.3) \\
& Comparison of the initial and current land area (Y2.4) \\
& The ability of businesses to compete is measured by \\
& business productivity (Y2.5) \\
& Farming income (Y2.6) \\
& Increase in production quantity/volume (Y2.7) \\
\hline
\end{tabular}

The research model is built with one exogenous latent variable $(X)$, namely personal characteristics, and two endogenous latent variables, namely entrepreneurial behavior (Y1) and business performance ( $\mathrm{Y} 2)$. The research model also involved fourteen manifest variables, as shown in Table 1 with the cross-model diagram in Figure 3.

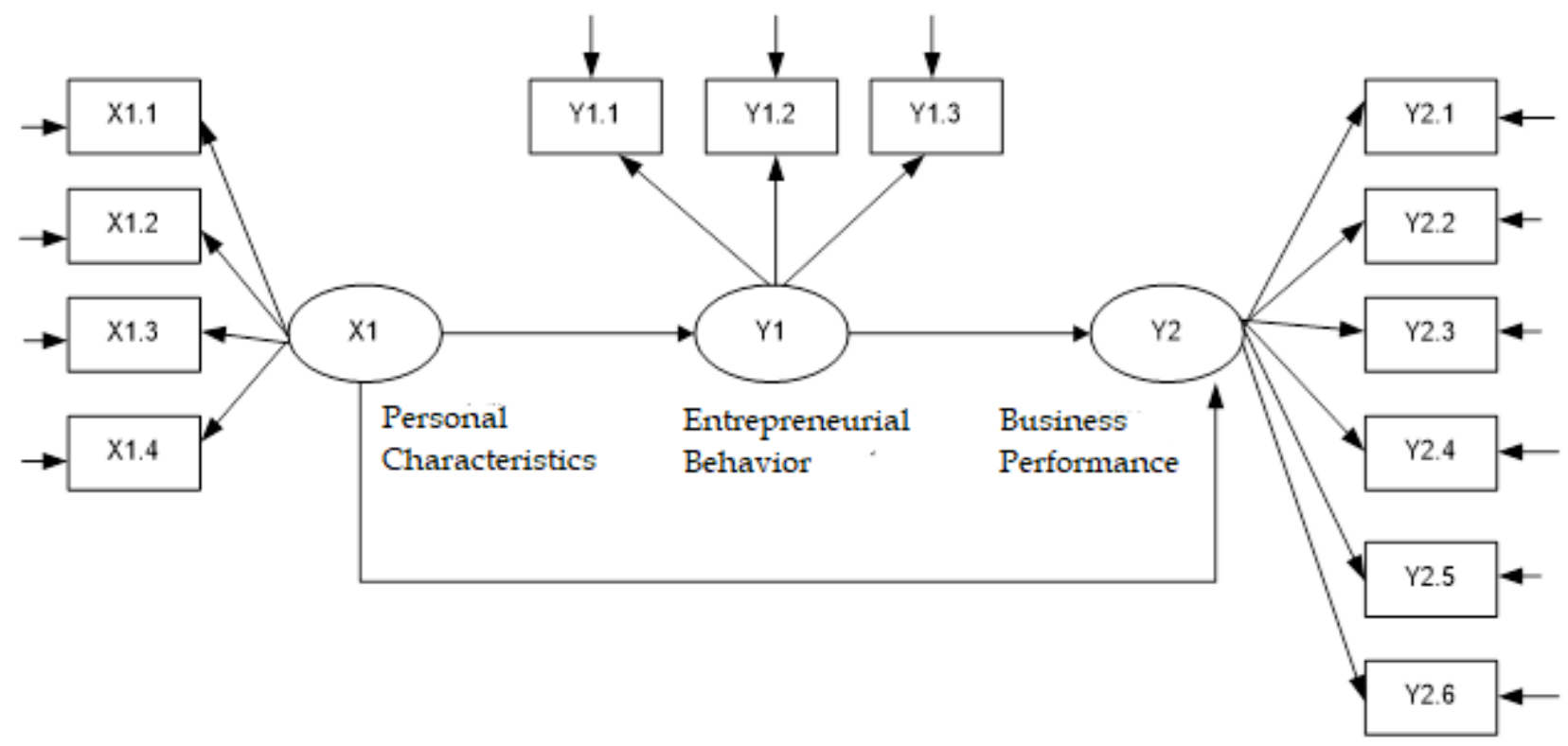

Figure 3. Cross-Model Diagram Research on the influence of Personal Characteristics on Performance through Entrepreneurial Behavior of Muntok White Pepper Farmers

Based on the research model built, there are three research hypotheses as follows:

H1: The personal characteristics of Muntok pepper farmers have a significant influence on their entrepreneurial behavior.

H2: The personal characteristics of Muntok pepper farmers have a significant influence on business performance.

H3: Personal characteristics have a significant influence on business performance through entrepreneurial behavior variables.

\section{Results and Discussion}

\subsection{Personal Characteristics of Pepper Farmers}

Farmers have an important role in determining the success of agricultural development. According to Burhanuddin et al. (2019), entrepreneurial farmers apply entrepreneurial attitudes in managing their farms, acting as farmers and entrepreneurs who can seize opportunities and 
take advantage of opportunities to increase profits. The problem of farmers' quality needs attention, considering that farmers have an important role in the development process. According to Sukananta et al. (2015), the quality of farmers is determined by the characteristics of the farmers themselves, such as age, education, and experience. Characteristics of farmers is a picture that reflects the situation of individuals in their lives based on socio-economic background.

In this study, farmers selected as respondents were entrepreneurial farmers identified as having entrepreneurial character and entrepreneurial behavior in managing Muntok pepper farming. The number of farmers involved as respondents was 90 farmers, and the personal characteristics of farmers were distinguished based on education, age, experience, and ethnic origin, as shown in Figure 4.

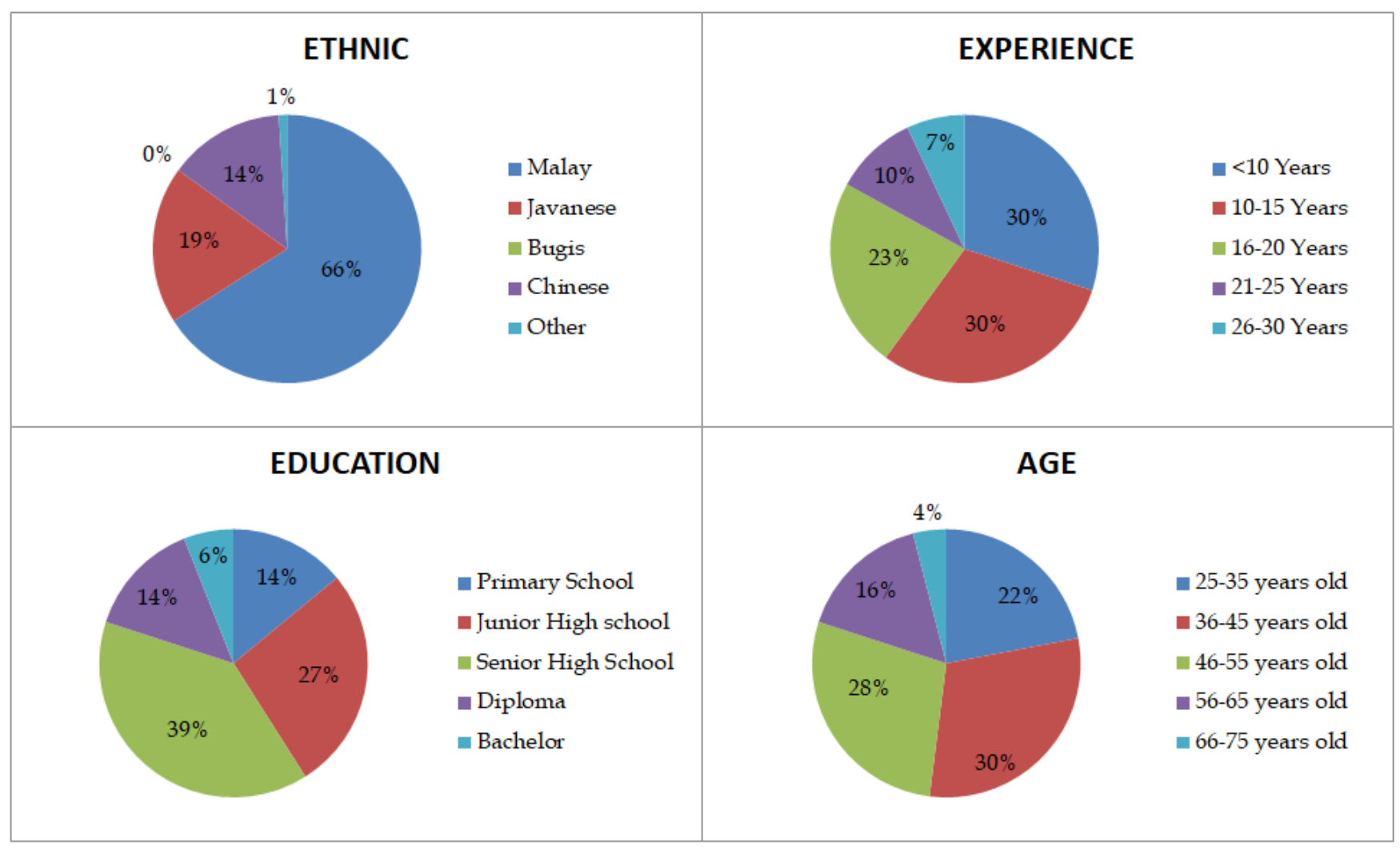

Figure 4. Personal characteristics of farmers by ethnic group, experience, education, and age

\subsubsection{Ethnic}

Figure 4 illustrates that farmers' personal characteristics are dominated by the Malay ethnic group, with a percentage of $66 \%$ or as many as 59 people. The personal characteristics of respondent farmers were also formed from groups of respondents with Javanese and Chinese ethnic origins, $19 \%$ and 14\%, respectively. This shows that ethnic Malay, Javanese, and Chinese ethnic groups form farmers' personal characteristics.

\subsubsection{Experience}

A person's decision to pursue a profession as an entrepreneur is influenced by the experience he has. The duration of farming of pepper farmers varies from 5 to 58 years, with an average length of business of 22 years. Figure 4 shows the personal characteristics of farmers based on experience, dominated by groups of farmers with years of experience in the range of 
10 to 15 years and under 10 years. Each group has 30\% or as many as 27 farmers in the 10-15 year group and 27 under the 10-year group. On the other hand, only $7 \%$ of farmers with experience between 25 or more 30 years or as many as 6 people.

\subsubsection{Education}

Education, in general, will affect farmers, both in acting and in thinking. Relatively higher education will cause farmers to be more dynamic. Educational factors have an important role in entrepreneurship because higher attitudes and skills are generally owned by people with higher education (Burhanuddin et al., 2019). Different opinions state that education does not determine the success of a business because there is no link between knowledge in formal education and the knowledge needed in managing a business (Riyanti, 2003) or in the decisionmaking process for certain activities (Bahtera et al., 2016). Figure 4 shows that respondent farmers' highest level of education is undergraduate, and the lowest is elementary school. The educational characteristics of respondents are dominated by farmers with a high school education level with a percentage of $39 \%$ or 35 people. On the other hand, the respondent farmers have the least education level, namely undergraduate with six per cent or five people.

\subsubsection{Age}

In general, age plays an important role in entrepreneurial behavior in improving business performance and is related to work performance. In addition, according to Riyanti (2003), it is not only chronological age that affects business success but is also related to the age of managing a business and increasing knowledge. With the increasing age of an entrepreneur, the success of managing a business is also very large. Based on Figure 4, the personal characteristics of the respondents based on the level of the age group are dominated by farmers aged 36 to 45 years, with a percentage of $30 \%$. On the other hand, the fewest respondent farmers are respondents aged 66 to 75 years, with $4 \%$. This shows that the dominant respondent farmer characteristics are formed by groups of farmers in the productive age range.

\subsection{Farmer Entrepreneurial Behavior}

The entrepreneurial behavior of pepper farmers in this study was measured based on the affective, cognitive, and motoric indicators of pepper farmers during the COVID-19 pandemic. According to Mitchelmore \& Rowley (2010), these affective, cognitive, and motoric indicators show a form of entrepreneurial ability. Farmer entrepreneurial behavior is all forms of entrepreneurial behavior carried out by farmers in managing pepper farming which is measured based on the assessment of farmers' perceptions.

Table 2. Percentage of assessment of farmers' perceptions of entrepreneurial behavior based on the perception rating category scale

\begin{tabular}{lcc}
\hline Perception category & Number of respondents (people) & Percentage (\%) \\
\hline Very high & 13 & 14.44 \\
High & 33 & 36.67 \\
Low & 42 & 46.67 \\
Very low & 2 & 2.22 \\
Total & $\mathbf{9 0}$ & $\mathbf{1 0 0}$ \\
\hline
\end{tabular}


Table 2 shows that the percentage of the assessment of the level of farmers' perceptions of entrepreneurial behavior shows the same results between the agree and disagree groups. However, based on the four perception category scales in Figure 4, it can be seen that the majority of respondents gave a perception assessment in the low category of farmer entrepreneurial behavior. Perceptions of 42 farmers or as much as $46.67 \%$, stated that they disagreed on several indicators of the entrepreneurial behavior assessment.

Table 3. Percentage of assessment of farmers' perceptions of entrepreneurial behavior based on assessment indicators

\begin{tabular}{lccc}
\hline \multirow{2}{*}{$\begin{array}{l}\text { Entrepreneurial } \\
\text { Behavior }\end{array}$} & \multicolumn{2}{c}{ Percentage of Farmers Answers (\%) } \\
\cline { 2 - 4 } & $\begin{array}{c}\text { Strongly } \\
\text { Disagree/Disagree }\end{array}$ & Neutral & Strongly Agree/Agree \\
\hline Affective & 0.22 & 0.24 & 0.58 \\
Cognitive & 0.08 & 0.34 & 0.54 \\
Motoric & 0.67 & 0.18 & 0.15 \\
\hline
\end{tabular}

Farmers' perceptions of the value of farmers' entrepreneurial behavior are measured based on three indicators: affective, cognitive, and motoric. Farmers' perceptions of affective and cognitive behavior indicators showed a high tendency where more than $50 \%$ of farmers agreed to agree. On the contrary, farmers' perceptions of motor indicator assessments were low, $67 \%$ of farmers stated disagreed to strongly disagreed on motor indicator assessments. This shows that the entrepreneurial behavior of pepper farmers is still dominantly shaped by attitudes and knowledge. These results also mean a perception assessment in the low category of farmer entrepreneurial behavior caused by $67 \%$ of farmers strongly disagree and disagree on the motoric indicator assessment. The results of previous research (Nursiah et al., 2017) also found that motoric indicators were still low in shaping the entrepreneurial behavior of tempeh craftsmen in Bogor Regency. Entrepreneurial behavior was still dominantly formed by knowledge indicators.

Farmers have a disciplined and tough attitude and will increase their knowledge and ability to minimize risks during the COVID-19 pandemic. The discipline and tough attitude shown by farmers, especially in pest control efforts, is the same as before the COVID-19 pandemic. Farmers also commit to continue to set aside income for farming capital, but problems of technical competence still constrain farmers. Farmers know about organic pepper farming but do not yet have sufficient skills to implement organic pepper farming.

\subsection{Business Performance}

Business performance is the result to be obtained in running a business to achieve goals. Price indicators can measure business performance, productivity, income, business expansion, market expansion, and sales volume (Puspitasari et al., 2013; Sumantri et al., 2013; Widiati \& Kusumastuti, 2013). According to Keh et al. (2007), business performance is also indicated by the desire to grow, such as income. Business performance in this study is measured based on competitiveness, business expansion, productivity, sales volume, and income. 
The Influence of Personal Characteristics on Performance through Entrepreneurial Behavior of Muntok Pepper Farmers

Table 4. Percentage of assessment of farmers' perceptions of business performance based on the perception rating category scale

\begin{tabular}{lcc}
\hline Perception category & Number of respondents (people) & Percentage (\%) \\
\hline Very high & 4 & 4.44 \\
High & 20 & 22.22 \\
Low & 63 & 70.00 \\
Very low & 3 & 3.33 \\
Total & $\mathbf{9 0}$ & $\mathbf{1 0 0}$ \\
\hline
\end{tabular}

Table 4 shows that the percentage of farmers' perceptions of the level of perception on business performance shows results belonging to the low category where as many as $70 \%$ or 63 farmers give a statement disagreeing on the performance appraisal indicators. This shows that at the beginning of the COVID-19 pandemic, there was no increase in business performance, or conversely, the COVID-19 pandemic caused business performance to decline, resulting in a low perception assessment result.

\subsection{Analysis of the Effect of Personal Characteristics on Performance through} Entrepreneurial Behavior of Muntok Pepper Farmers Evaluation of Measurement Model

The main purpose of evaluating the measurement model is to determine whether an indicator (manifest variable) can measure the construct (latent variable). The results of the measurement model analysis (Outer Model) through the PLS algorithm process show that the overall factor loading value obtained is more than 0.5 , and there is only one invalid indicator with a factor loading value below 0.5 , namely the educational indicator variable. This means that the overall indicators used can measure the construct. The overall indicators of the variables measured are valid, reflecting personal characteristics, entrepreneurial behavior, and business performance variables.

Validity is also evidenced by the t-value obtained by all of them, greater than 1.96 (Table 5). The loading factor value in Table 5 shows that indicators of ethnic origin strongly reflect the latent personal characteristics of the pepper farmers. In contrast, in the latent entrepreneurial behavior and performance, there are indicators of cognitive (knowledge) and business productivity that most strongly reflect latently.

Table 5. Contribution of Personal Characteristics Indicator Variables based on Loading Factor Value and T-value, as well as Observation Variable Reliability

\begin{tabular}{cccccccc}
\hline $\begin{array}{c}\text { Latent } \\
\text { Variable }\end{array}$ & $\begin{array}{c}\text { Manifest } \\
\text { Variable }\end{array}$ & $\begin{array}{c}\text { Loading } \\
\text { Factor }\end{array}$ & $\begin{array}{c}\text { T- } \\
\text { value }\end{array}$ & $\begin{array}{c}\text { Cronbach' } \\
\text { s Alpha }\end{array}$ & AVE & Validity & Reliability \\
\hline Personal Characteristics (X) & & & & & & \\
\hline Education & 0.307 & 1.335 & & & Invalid & \\
Age & 0.604 & 2.335 & 0.889 & 0.533 & Valid & Reliable \\
Experience & 0.616 & 2.148 & & & Valid & \\
Ethnic origin & 0.722 & 2.518 & & & & \\
\hline Entrepreneurial Behavior (Y1) & & & & & Valid & \multirow{2}{*}{ Reliable } \\
\hline Affective & 0.819 & 5.740 & & & Valid & Valid & \\
cognitive & 0.842 & 5.758 & 0.748 & 0.592 & & \\
Motoric & 0.629 & 2.439 & & & & & \\
\hline
\end{tabular}

Copyright (C) 2020. Owned by Author(s), published by Society. This is an open-access article under the CC-BY-NC-SA license. https://doi.org/10.33019/society.v8i2.249 
The Influence of Personal Characteristics on Performance through Entrepreneurial Behavior of Muntok Pepper Farmers

\begin{tabular}{cccccccc}
\hline $\begin{array}{c}\text { Latent } \\
\text { Variable }\end{array}$ & $\begin{array}{c}\text { Manifest } \\
\text { Variable }\end{array}$ & $\begin{array}{c}\text { Loading } \\
\text { Factor }\end{array}$ & $\begin{array}{c}\text { T- } \\
\text { value }\end{array}$ & $\begin{array}{c}\text { Cronbach' } \\
\text { s Alpha }\end{array}$ & AVE & Validity & Reliability \\
\hline Business Performance (Y2) & & & & & & \\
\hline $\begin{array}{l}\text { Comparison of } \\
\text { increase in planted } \\
\text { area (Y2.3) }\end{array}$ & 0.784 & 5.567 & & Valid & \\
$\begin{array}{l}\text { Comparison of } \\
\text { initial and current } \\
\text { land area (Y2.4 }\end{array}$ & 0.861 & 6.055 & & Valid & Reliable \\
$\begin{array}{l}\text { Business } \\
\text { productivity (Y2.5) }\end{array}$ & 0.885 & 7.251 & & & Valid & \\
$\begin{array}{l}\text { Farming income } \\
\text { (Y2.6) }\end{array}$ & 0.603 & 2.790 & & Valid & \\
\hline
\end{tabular}

Evaluation of the measurement model is also done by assessing the reliability based on the AVE and Composite Reliability (CR) values. Reliability is the consistency of a measurement that aims to test the consistency of each statement in the questionnaire as a measurement of a latent variable (Haryono \& Wardoyo, 2015). The results of data analysis on the measurement model also provide information that the indicator variables used to meet the reliable requirements. All of Cronbach's Alpha values show numbers greater than 0.7 , and the average extracted variance (AVE) is greater than 0.5 (Table 5). This means that all of the variable indicators used are truly reliable in measuring the construct.

\subsubsection{Structural Model Evaluation}

The purpose of evaluating the structural model is to see the relationship between latent constructs and the estimated path parameter coefficients and their significance level (Ghozali \& Latan, 2012). The evaluation of the structural model in this study was conducted to see three forms of latent construct relationships, namely the influence of personal characteristics on entrepreneurial behavior (H1), the influence of entrepreneurial behavior on performance (H2), and the influence of personal characteristics on performance (H3). Analysis of the three forms of the relationship shows that in addition to looking at the effect of personal characteristics on performance through farmer entrepreneurship variables, the researchers also prove whether there is a direct influence of personal in the case of Muntok pepper farmers characteristics on performance. The significant test results of all hypotheses built in this study can be seen in Table 6.

Table 6. Coefficient Value of Path Parameters Influence of Personal Characteristics on Entrepreneurial Behavior

\begin{tabular}{|c|c|c|c|c|}
\hline Hypothesis & & Original Sample & $\mathrm{t}$-value & Result \\
\hline $\begin{array}{l}\text { Personal Characteristics > } \\
\text { Entrepreneurial Behavior }\end{array}$ & & 0.447 & 2.060 & Signifikan \\
\hline $\begin{array}{l}\text { Entrepreneurial Behavior } \\
\text { Performance }\end{array}$ & $>$ Business & 0.237 & 2.231 & Signifikan \\
\hline $\begin{array}{l}\text { Personal Characteristics } \\
\text { Performance }\end{array}$ & $>$ Business & 0.122 & 0.740 & Tidak Signifikan \\
\hline
\end{tabular}

*Significance of $\mathrm{t}(0.05): 1.96)$ 
The structural model evaluation results in Table 6 show that the t-value of the causal relationship of personal characteristics to entrepreneurial behavior (H1) and the causal relationship of entrepreneurial behavior to performance $(\mathrm{H} 2)$ is greater than the standard 1.96, namely 2.060 and 2.231. There is a significant effect on both causal relationships, and there is no significant effect on the causal relationship of personal characteristics on performance (H3). The Original Sample value in Table 6 shows the magnitude of the coefficient value of the path parameter and the direction of the relationship between the two variables. The greater the coefficient value, indicating the influence of the estimated variables is getting stronger. In other words, the causal relationship is the most important in the model. This shows that the most important causal relationship for the business performance variable is the entrepreneurial variable, namely the entrepreneurial behavior of Muntok pepper farmers.

The coefficient value of the influence of entrepreneurial behavior on business performance is 0.237 greater than the value of the influence of personal characteristics on performance, which is 0.122 . The results obtained provide information that the entrepreneurial behavior of Muntok pepper farmers, such as attitudes (affective), knowledge (cognitive), and skills (motoric) owned by farmers, is more important in influencing performance than the farmers' personal characteristics such as age, experience and ethnic origin.

Table 6 also provides information that there is a significant influence of personal characteristics on entrepreneurial behavior where the coefficient value obtained is also large, namely 0.447 . This shows that personal characteristics have an influence on performance through entrepreneurial behavior variables. This means that age, experience, and ethnic origin as indicators of farmer personal characteristics variables influence performance through entrepreneurial behavior in farming. This is shown by the attitude, knowledge, and skills possessed. The results obtained indicate that it is not enough to rely on their abilities to improve the performance of farmers' businesses. Still, entrepreneurship is needed so that self-efficacy formed from experience, ethnic origin, and age can improve business performance. Efforts to improve agribusiness performance need to be accompanied by paying attention to human resource factors, entrepreneurship development, and the development of entrepreneurial farmers are priorities (Krisnamurthi, 2010).

\subsubsection{Influence of Personal Characteristics on Entrepreneurial Behavior (H1)}

The results of the study found the influence of personal characteristics on entrepreneurial behavior. These personal characteristics are individual internal factors that influence entrepreneurial behavior. This means that the entrepreneurial behavior of Muntok pepper farmers is influenced by individual internal factors, in addition to being influenced by personal characteristics. According to Astuti et al. (2019), the entrepreneurial behavior of Muntok pepper farmers is also influenced by the entrepreneurial character of farmers who are willing to innovate, dare to take risks, and are responsive to opportunities.

The results of the study found that personal characteristics have a positive influence on entrepreneurial behavior. This means that increasing the value of the variables of age, experience, and ethnic origin increases farmer entrepreneurship through changes in the values of their attitudes, knowledge, and skills. The results of the same study found the influence of personal characteristics on entrepreneurship, in this case, is the motivation of farmers (Sumantri et al., 2013). Personal characteristics such as education, training, age, ethnic origin, experience, and family background affect the motivation of farmers to be entrepreneurs. 


\section{The Influence of Personal Characteristics on Performance through Entrepreneurial Behavior of}

Muntok Pepper Farmers

The personal characteristics of the Muntok pepper farmers in this study were dominantly formed by the variables of ethnic origin, experience, and age, while education was not valid. This shows that pepper farmer entrepreneurship is not determined by formal education. This is because pepper cultivation is a cultural heritage carried out from generation to generation. It can be ascertained that there is no need for formal education but rather formal education or training. Farmer entrepreneurship is largely shaped by experience and age. This is because the longer the business experience, the more training followed and more knowledge obtained. Meanwhile, farmers' skills are determined by the productivity of the farmer's age. The more productive the farmers, the easier it is for them to receive and practice the training materials and desire to increase their knowledge.

Farmer entrepreneurship is also determined by ethnic origin. So far, ethnic Javanese and Chinese farmers are more disciplined, tough, and tenacious in farming. However, the personal characteristics of these farmers need to be supported by capital ability and the carrying capacity of the environment to achieve the desired business performance. According to Sumantri et al. (2013), women entrepreneurs in Javanese and Chinese ethnicity are more diligent in trying and desire to grow, but still need to be supported by capital capabilities to achieve the expected performance.

\subsubsection{The Effect of Entrepreneurial Behavior on Performance (H2)}

This study also found a direct and significant influence on the entrepreneurial behavior variable on business performance. Table 6 shows that there is a positive influence between the variables of entrepreneurial behavior and business performance. This means that business performance can be improved through efforts to improve the entrepreneurial behavior of farmers, especially in the skills (motoric) indicators. The path parameter coefficient value of the two variable relationships is 0.237 , which is still relatively low (Table 6). The performance of Muntok pepper farming is influenced by human resource factors (internal factors) and needs external environmental support, especially on government policies to monitor pepper prices.

Muntok pepper entrepreneurial behavior, according to Astuti et al. (2019), can be seen from the indicators of attitude (affective), knowledge (cognitive), and skills (motoric). Knowledge indicator variable (Cognitive) has the most dominant contribution in reflecting the entrepreneurial behavior of farmers. The same result was also found in this study that the knowledge indicator is still the most dominant variable that reflects the entrepreneurial behavior of farmers during the COVID-19 pandemic. Meanwhile, farmer skills are still the weakest variable reflecting farmer entrepreneurship. This means that the COVID-19 pandemic has not impacted the persistence of farmers to increase knowledge from various sources of information. Still, farmers are constrained in improving their skills because during the COVID19 pandemic the intensity of the training they participate in decreases, activities in farmer groups are less active. Farmers still need continuous assistance to become skilled farmers.

The relationship between entrepreneurial behavior and business performance in the general model adopted from Delmar (1996), can be obtained directly without intermediaries. The results of previous studies found that the entrepreneurial behavior of rubber farmers in Jambi and orchid farmers in Bogor had a positive influence on their business performance. The better the behavior of the business performance, the more the business performance will increase (Puspitasari et al., 2013). The entrepreneurial behavior of tempeh craftsmen in Bogor also positively influences business performance, and the entrepreneurial behavior of tempeh craftsmen is most dominantly reflected in cognitive indicators (Nursiah et al., 2017).

Copyright (C 2020. Owned by Author(s), published by Society. This is an open-access article under the CC-BY-NC-SA license. 
Entrepreneurial behavior influences business performance through changes in income, sales, and competitive ability (Dirlanudin et al., 2010; Puspitasari et al., 2013).

\subsubsection{Effect of Personal Characteristics on Performance (H3)}

The results of this study did not find a significant effect on the personal characteristics variable on business performance directly. The $t$-value obtained is 0.740 , which is smaller than the standard of significance, which is 1.96. This shows that farmers' experience, the increasingly productive age of farmers, and the diligent and persistent nature of ethnic origin alone are not reliable enough to affect performance. Farmers can achieve business performance at a better level by behaving entrepreneurially in managing their business. The results of previous studies found a significant effect of the personal characteristics of women entrepreneurs in the homebased food industry in Bogor on business performance directly. Sumantri et al. (2013) stated that personal characteristics are the most important variables determining business performance compared to entrepreneurship which has a negative relationship between entrepreneurship and performance. This is because women entrepreneurs so far rely heavily on their abilities.

Fritz Heider's attribution theory provides an overview of how internal factors influence individual behavior, namely attributes attached to personal traits and qualities, in this case, including personal characteristics. The general model of entrepreneurial behavior and business performance adopted from Delmar (1996) also shows that the relationship between internal factors and business performance is obtained through entrepreneurial behavior variables, not a direct relationship. Individual internal factors do not directly affect the integration of crops and livestock performance but through farmer entrepreneurship. Business performance is determined by individual actions or behavior in decision-making, namely the actions of farmers trying to achieve goals by persistently and diligently working hard, looking for opportunities, having managerial abilities, and making decisions amid uncertainty.

This means that the personal characteristics possessed can influence the behavior of farmers in entrepreneurship, and in the end, this behavior affects the performance of Muntok pepper farmers. These results indicate that to restore the glory of Muntok pepper through improving business performance, the government also needs to pay attention to human resource factors. In this case, farmers, planners, and business decision-makers. Muntok pepper farmers have also been identified as having entrepreneurial characteristics, and those who are members of farmer groups are more capable of entrepreneurial behavior in managing their farming (Astuti et al., 2019).

\section{Conclusion}

Indicators of ethnic origin dominantly reflect the personal characteristics of Muntok pepper farmers, but experience and age are also valid to reflect farmers' personal characteristics. Personal characteristics have been proven to contribute positively and significantly to entrepreneurial behavior and significant positive entrepreneurial behavior to influence business performance. The study results found that the influence of personal characteristics on business performance, not directly but through entrepreneurial behavior. The development of entrepreneurial farmers can be carried out to improve business performance by providing guidance, assistance, and training that pays attention to farmers' personal characteristics and entrepreneurship, especially the entrepreneurial behavior of farmers in Muntok pepper cultivation activities.

Copyright (C 2020. Owned by Author(s), published by Society. This is an open-access article under the CC-BY-NC-SA license. https://doi.org/10.33019/society.v8i2.249 


\section{Acknowledgment}

The authors would like to thank you for the financial support and facilities to make this research successful through the 2020 Beginner Lecturer Research Grant Scheme awarded by the Directorate General of Research and Development Strengthening, Ministry of Research, Technology and Higher Education of the Republic of Indonesia. The authors also thank the Institute for Research and Community Service, Universitas Bangka Belitung, for administrative support during this research.

\section{Declaration of Conflicting Interests}

The authors have declared no potential conflicts of interest concerning the study, authorship, and/or publication of this article,

\section{References}

Astuti, R. P., Bahtera, N. I., \& Atmaja, E. J. J. (2019). Entrepreneurial Characteristics and Behaviors of Muntok White Pepper Farmers. Society, 7(2), 101-115. https:// doi.org/10.33019/ society.v7i2.116

Bahtera, N. I., Arshad, F. M., Sidique, S. F., Djama, M., \& Abu-samah, A. (2016). The determinants of participation in empowerment programs in Jambi Province, Indonesia. Asia Pacific Journal of Advanced Business and Social Studies, 2(2), 534-550. Retrieved from https:/ / apiar.org.au/journal-paper/the-determinants-of-participation-inempowerment-programs-in-jambi-province-indonesia/

Bannor, R. K., Ros-Tonen, M. A., Mensah, P. O., Derkyi, M., \& Nassah, V. F. (2020). Entrepreneurial behaviour among non-timber forest product-growing farmers in Ghana: An analysis in support of a reforestation policy. Forest Policy and Economics, 122, 102331. https:// doi.org/10.1016/j.forpol.2020.102331

Brush, C. G., de Bruin, A., Gatewood, E. J., \& Henry, C. (Eds.). (2010). Women Entrepreneurs and the Global Environment for Growth. Cheltenham, UK: Edward Elgar Publishing. https:/ / doi.org/10.4337/9781849806633

Burhanuddin, B., Pambudy, R., \& Wahyudi, A. F. (2019). Analisis Karakteristik Kewirausahaan dan Adopsi Inovasi Petani Kopi di Provinsi Lampung. Jurnal Agribisnis Indonesia, 6(2), 73. https:// doi.org/10.29244/jai.2018.6.2.73-84

Calza, F., Cannavale, C., \& Zohoorian Nadali, I. (2020). How do cultural values influence entrepreneurial behavior of nations? A behavioral reasoning approach. International Business Review, 29(5), 101725. https:/ / doi.org/10.1016/j.ibusrev.2020.101725

de Bernardi, C., \& Pedrini, M. (2020). Entrepreneurial behaviour: Getting eco-drunk by feeling environmental passion. Journal of Cleaner Production, 256, 120367. https:// doi.org/10.1016/j.jclepro.2020.120367

Delmar, F. (1996). Entrepreneurial Behavior and Business Performance. Stockholm: Ekonomiska Forknings Institute.

Dirlanudin, D., Sarma, M., Asngari, P. S., \& Susanto, D. (2010). Perilaku wirausaha dan keberdayaan pengusaha kecil industri agro: Kasus di Kabupaten Serang Provinsi Banten (Dissertation). IPB University. Retrieved https:// repository.ipb.ac.id/handle/123456789/55034

Donbesuur, F., Boso, N., \& Hultman, M. (2020). The effect of entrepreneurial orientation on new venture performance: Contingency roles of entrepreneurial actions. Journal of Business Research, 118, 150-161. https:/ / doi.org/10.1016/j.jbusres.2020.06.042 
FAOSTAT. (2019). FAOSTAT. Retrieved from http://www.fao.org/faostat/en/

Ghozali, I., \& Latan, H. (2012). Partial Least Squares: Konsep, Teknik dan Aplikasi Smart PLS 2.0 M3. Semarang: Universitas Diponegoro.

Haryono, S., \& Wardoyo, P. (2015). Structural Equation Modeling Untuk Penelitian Manajemen Menggunakan Amos 18.00. (S. Hamid Mintardja, Ed.). Bekasi: PT. Intermedia Personalia Utama.

Irawati, E., \& Yantu, M. R. (2015). The Performance of Farmer Institutional to Support Farm Income of Rice Wetlandat. Agrotekbis, 3(2), 206-211.

Islam, M. A., Khan, M. A., Obaidullah, A. Z. M., \& Alam, M. S. (2011). Effect of Entrepreneur and Firm Characteristics on the Business Success of Small and Medium Enterprises (SMEs) in Bangladesh. International Journal of Business and Management, 6(3), 289-299. https:/ / doi.org/10.5539/ijbm.v6n3p289

Jumaedi, H. (2012). Hubungan karakteristik wirausaha terhadap keberhasilan usaha (studi kasus pada pengusaha kecil di Pekalongan). Manajerial: Jurnal Manajemen dan Sistem Informasi, 11(2), 13-19. $\quad$ Retrieved from https:// ejournal.upi.edu/index.php/manajerial/article/view/2171

Keh, H. T., Nguyen, T. T. M., \& Ng, H. P. (2007). The effects of entrepreneurial orientation and marketing information on the performance of SMEs. Journal of Business Venturing, 22(4), 592-611. https:/ / doi.org/10.1016/j.jbusvent.2006.05.003

Kellermanns, F. W., Eddleston, K. A., Barnett, T., \& Pearson, A. (2008). An Exploratory Study of Family Member Characteristics and Involvement: Effects on Entrepreneurial Behavior in the Family Firm. Family Business Review, 21(1), 1-14. https://doi.org/10.1111/j.17416248.2007.00107.x

Krisnamurthi, B. (2010). Refleksi Agribisnis: 65 Tahun Profesor Bungaran Saragih /Bayu Krisnamurthi. Bogor: IPB Press.

Kuntariningsih, A., \& Mariyono, J. (2013). Dampak Pelatihan Petani Terhadap Kinerja Usahatani Kedelai Di Jawa Timur. Sosiohumaniora, 15(2), 130. https:// doi.org/10.24198/sosiohumaniora.v15i2.5739

Li, X. (2009). Entrepreneurial Competencies as an Entrepreneurial Distinctive: An Examination of the Competency Approach in Defining Entrepreneurs (Dissertation). Singapore Management University.

Metallo, C., Agrifoglio, R., Briganti, P., Mercurio, L., \& Ferrara, M. (2020). Entrepreneurial Behaviour and New Venture Creation: the Psychoanalytic Perspective. Journal of Innovation \& Knowledge, 6(1), 35-42. https:/ / doi.org/10.1016/j.jik.2020.02.001

Miftakhuljanah, O., Priatna, W. B., \& Suharno, S. (2016). Karakter Wanita Wirausaha Pada Industri Kecil Kerupuk Kemplang Di Kabupaten Ogan Ilir. Jurnal Agribisnis Indonesia, 4(2), 123. https:/ / doi.org/10.29244/jai.2016.4.2.123-136

Mitchelmore, S., \& Rowley, J. (2010). Entrepreneurial competencies: a literature review and development agenda. International Journal of Entrepreneurial Behavior E Research, 16(2), $92-$ 111. https:/ / doi.org/10.1108/13552551011026995

Nurfitriya, M. (2013). Pengaruh Sikap Kewirausahaan Terhadap Perkembangan Usaha Pada Pengusaha Batik Di Sentra Kerajinan Batik Kota Tasikmalaya (Thesis). Universitas Pendidikan Indonesia. Retrieved from http:/ / repository.upi.edu/3250/

Nurhayati, P. (2011). Karakteristik dan Kinerja Wirausaha Wanita pada UKM Agroindustri Perikanan di Kabupaten Sukabumi. In R. Nurmalina, W. B. Priatna, S. Jahroh, P. Nurhayati, \& A. Rifin (Eds.), Prosiding Seminar Penelitian Unggulan Departemen Agribisnis

Copyright (C 2020. Owned by Author(s), published by Society. This is an open-access article under the CC-BY-NC-SA license. 
The Influence of Personal Characteristics on Performance through Entrepreneurial Behavior of Muntok Pepper Farmers

(pp. 271-285). Bogor, Indonesia. Retrieved from https:/ / repository.ipb.ac.id/jspui/bitstream/123456789/65350/1/11.pdf

Nursiah, T., Kusnadi, N., \& Burhanuddin, B. (2017). Perilaku Kewirausahaan pada Usaha Mikro Kecil (UMK) Tempe di Bogor Jawa Barat. Jurnal Agribisnis Indonesia, 3(2), 145. https:/ / doi.org/10.29244/jai.2015.3.2.145-158

Priyono, P., \& Burhanuddin, B. (2020). Penumbuhkembangan Perilaku Kewirausahaan Dalam Sistem Agribisnis Ayam Lokal. Journal of Integrated Agribusiness, 2(1), 62-76. https:/ / doi.org/10.33019/jia.v2i1.1765

Puspitasari, P., Nurmalina, R., \& Fariyanti, A. (2013). Pengaruh Perilaku Kewirausahaan Petani Anggrek Terhadap Kinerja Usaha: Kasus di Kecamatan Gunung Sindur dan Parung, Kabupaten Bogor, serta Kecamatan Serpong, Kota Tangerang Selatan (Master Theses). IPB University. Retrieved from https:// repository.ipb.ac.id/handle/123456789/64234

Riyanti, B. P. D. (2003). Kewirausahaan Dari Sudut Pandang Psikologi Kepribadian. Jakarta: PT. Grasindo.

Sapar, S., Lumintang, R. W., \& Susanto, D. (2006). Faktor-Faktor Yang Berkaitan Dengan Perilaku Kewirausahaan Pedagang Kaki Lima (Kasus Pedagang Kaki Lima Pemakai Gerobak Usaha Makanan Di Kota Bogor). Jurnal Penyuluhan, 2(2). https:// doi.org/10.25015/penyuluhan.v2i2.2131

Sari, N. M. W., Suwarsinah, H. K., \& Baga, L. M. (2016). Pengaruh Karakteristik Kewirausahaan terhadap Kinerja Usaha Mikro, Kecil dan Menengah(UMKM) Gula Aren di Kabupaten Lombok Barat. Jurnal Penyuluhan, https:// doi.org/10.25015/penyuluhan.v12i1.11320

Sukananta, I. K., Dukat, \& Yuniati, A. (2015). Hubungan karakteristik dan motivasi petani dengan kinerja kelompok tani. Jurnal Agrijati, 28(1), 1-15. Retrieved from http://jurnal.ugj.ac.id/index.php/agrijati/article/view/169

Sumantri, B., Fariyanti, A., \& Winandi, R. (2013). Pengaruh jiwa kewirausahaan terhadap kinerja usaha wirausaha wanita pada industri pangan rumahan di Bogor (Master Theses). IPB University. Retrieved from https:// repository.ipb.ac.id/handle/123456789/66852

Widiati, R., \& Kusumastuti, T. A. (2013). Manajemen Agribisnis: Aplikasi pada Industri Peternakan. (B. S. Hertanto, Ed.) (1st ed.). Yogyakarta, Indonesia: CGS Press.

Yulia, N., \& Bahtera, N. I. (2020). Faktor-Faktor Yang Mempengaruhi Efisiensi Teknis Lada Putih Di Provinsi Kepulauan Bangka Belitung. Jurnal Hexagro, 4(1). https:/ / doi.org/10.36423/hexagro.v4i1.367

\section{About the Authors}

1. Rufti Puji Astuti, obtained her Master's degree in Agribusiness Science from IPB University, Indonesia, in 2016. The author is an Assistant Professor at the Department of Agribusiness, Faculty of Agriculture, Fisheries, and Biology, Universitas Bangka Belitung, Indonesia.

E-Mail: ruftipuji24@gmail.com 
2. Novyandra Ilham Bahtera obtained his Master's degree from Universiti Putera Malaysia in 2016. The author is an Assistant Professor at the Department of Agribusiness, Faculty of Agriculture, Fisheries, and Biology, Universitas Bangka Belitung, Indonesia.

E-Mail: novyandra.ib@gmail.com

3. Eddy Jajang Jaya Atmaja obtained his Master's degree from Universitas Timbul Nusantara, Jakarta, Indonesia, in 2001. The author is an Assistant Professor at the Department of Agribusiness, Faculty of Agriculture, Fisheries, and Biology, Universitas Bangka Belitung, Indonesia.

E-Mail: eddyjajangjaya@gmail.com

4. Igu Sandira, a student at the Department of Agribusiness, Faculty of Agriculture, Fisheries, and Biology, Universitas Bangka Belitung, Indonesia.

E-Mail: igutoboali123@gmail.com 